\title{
INTRODUCTION TO GEOLOGY
}

\section{Volume 2 Earth History}

Part II Later Stages of Earth History 


\section{Introduction to Geology}

Volume 2 Earth History

\section{Part II Later Stages of Earth History}

H. H. READ

F.R.S., F.R.S.E., F.G.S., D.Sc., A.R.C.S.

Sometime Professor Emeritus of Geology, Imperial College of Science and Technology, University of London

JANET WATSON

Ph.D., A.R.C.S., D.I.C.

Professor of Geology in the University of London, Imperial College of Science and Technology,

London 
(c) The Estate of the late H. H. Read and Janet Watson 1975

Softcover reprint of the hardcover 1st edition 1975 978-0-333-17668-9

All rights reserved. No part of this publication may be transmitted, in any form or by any means, without permission.

\author{
First published 1975 by \\ THE MACMILLAN PRESS LTD \\ London and Basingstoke \\ Associated companies in New York Dublin \\ Melbourne Johannesburg and Madras
}

SBN 333176685 (hard cover) SBN 333176693 (paper cover)

Typeset by

PREFACE LIMITED Salisbury, Wilts and printed by

COMPTON PRINTING

Aylesbury, Bucks and bound by

PITM AN PRESS

Bath, Avon

ISBN 978-0-333-17669-6

ISBN 978-1-349-15613-9 (eBook)

DOI 10.1007/978-1-349-15613-9

Library of Congress Catalog Card No. 75-501

The paperback edition of this book is sold subject to the condition that it shall not by way of trade or otherwise, be lent, re-sold, hired out or otherwise circulated without the publisher's prior consent in any form of binding or cover other than that in which it is published and without a similar condition including this condition being imposed on the subsequent purchaser. 


\section{Contents}

List of figures vii

List of plates $\mathrm{x}$

Preface $\quad$ xi

Acknowledgements $\quad$ xii

1 New Themes in Earth History 1

2 The Caledonides and their Forelands 16

3 The Hercynides and Uralides with their Forelands 58

4 The Appalachians and Interior Lowlands of the North American Craton 99

5 Gondwanaland in Late Proterozoic and Early Palaeozoic Times 131

6 Gondwanaland in Late Palaeozoic Times 159

7 The Alpine-Himalayan Belt and the Eurasian Craton 179

8 Gondwanaland: Disruption of a Supercontinent 223

9 The New Ocean Basins $\quad 252$

10 The Pacific Ocean and its Island Arcs 282

11 The Cordilleran and Andean Mobile Belts and the North American
Craton

$\begin{array}{lr}\text { Bibliography } & 341\end{array}$

$\begin{array}{ll}\text { Index } & 353\end{array}$ 


\section{List of Figures}

1.1 The fit of the American, African and European continents at the 500 fathom line

1.2 Permo-Carboniferous glaciation relative to the palaeopoles

1.3 Latitudes of occurrences of corals and evaporites plotted against age

1.4 Polar wandering curves for Europe and North America

1.5 Polar wandering curves for South America and Africa

1.6 Movement of Australia relative to the South Pole from Carboniferous times onwards

1.7 Principal crustal plates of the earth today

2.1 Mobile belts and cratons of Laurasia in early Palaeozoic times

2.2 Major components of some basin-successions deposited in the Caledonian mobile belt of north-west Europe, East Greenland and Spitsbergen

2.3 Caledonian mobile belt in Britain

2.4 Highland area of the British Caledonides 22

$\begin{array}{ll}2.5 & \text { Caledonides of East Greenland } \\ 2.6 & 25\end{array}$

2.6 Caledonides of Scandinavia 30

2.7 Inferred structure of the British Caledonides after infilling of later basins of deposition but before end-Silurian folding and uplift

2.8 Variations of thickness and facies in the Lower Palaeozoic basin of the Southern Uplands

2.9 Principal outcrops of Lower Palaeozoic on the eastern foreland of the Caledonides

2.10 Basement-cover relationships in the Highland zone of the British Caledonides

2.11 Metamorphic map of the Highland zone of the Caledonides in Scotland

2.12 The Old Red Sandstone continent

3.1 Hercynian mobile belts in Europe and western Asia 59

3.2 Structural zones of the Hercynides 60

3.3 Hercynian massifs of central Europe showing units of the Palaeozoic succession and important coalfields

3.4 Hercynian massifs of western Europe 63

3.5 The Ardennes and Rhenish Schiefergebirge with diagrammatic section across the eastern Ardennes

3.6 Variations of thickness and facies in the Devonian of the Ardennes

3.7 Facies variations in the Lower Carboniferous of the Hercynian foreland in Britain 
3.8 Hercynian plutonism

3.9 Hercynian mineralisation in western Europe

3.10 Pennsylvanian coal-measure facies in relation to the HercynianAppalachian mobile belt

3.11 Major lineaments and faults in central and western Europe 87

3.12 Post-orogenic deposition on the Hercynian foreland 88

3.13 Main geological units of the Uralides

3.14 Salt-tectonics in the post-Hercynian cover of part of the European craton

4.1 Appalachian and Ouachita mobile belts

4.2 Southern Appalachians

4.3 North American craton showing the larger basins and uplifts

4.4 Northern Appalachians

4.5 Refolded nappes in the Appalachian eugeosynclinal zone of New England

4.6 Clastic wedges deposited near the north-western border of the Appalachians

4.7 Bouguer gravity-anomalies in relation to the Blue Ridge province

4.8 The Valley and Ridge Province

4.9 Preliminary data showing variations in crustal thickness in North America

4.10 Palaeozoic successions of the North American craton

4.11 Timing of critical events in several sectors of the CaledonianAppalachian mobile belt

4.12 Variations in the terminal stages of mobility in the CaledonianAppalachian mobile belt

5.1 Early Phanerozoic mobile belts of Gondwanaland

5.3 Mozambique belt

5.4 Polycyclic complexes of Ceylon 143

$\begin{array}{ll}5.5 & \text { Adelaidean mobile belt } \\ 5.6 & 145\end{array}$

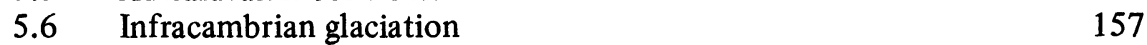

6.1 Gondwanaland in mid-Palaeozoic times 160

6.2 Australia: distribution of middle and late Palaeozoic strata and principal basins of deposition

6.3 Basin-successions in the southern part of the Tasman belt 170

6.4 Migration of sites of granite formation in the Tasman belt 172

$\begin{array}{ll}\text { 6.5 Gondwanaland in Permian times } & 176\end{array}$

6.6 Palaeoclimatic indicators for late Triassic times 178

7.1 Peripheral mobile belts of the supercontinents in early Mesozoic times

7.2 Components of the Alpine-Himalayan belt in Europe 182

7.3 Major tectonic units of the western, central and eastern Alps $\quad 189$

7.4 Mobile belts and marine basins of the eastern Mediterranean 190

7.5 Distribution in time and space of syn-orogenic sediments of flysch facies in parts of the Alpine system of mobile belts

7.6 Simplified cross-section of the western Alps

7.7 Regional metamorphism in relation to structure in the western Alps 
7.9 Crustal structure inferred from seismological observations in a section of Eurasia from the Black Sea to Tien Shan

7.10 Relationships of marine and non-marine Palaeogene sediments near the southern border of the Paris basin

7.11 Rhine-graben with associated faults and Neogene volcanics in the European craton

7.12 Principal tectonic units of the Himalayas

8.1 Distribution of Permian and early Mesozoic non-marine formations in the supercontinent of Gondwanaland

8.2 Marginal Mesozoic and Tertiary basins of western Africa

8.3 Rift valley system of eastern Africa

8.4 Erosion-surfaces in southern and eastern Africa

8.5 Distribution in time and space of volcanics associated with the Eastern Rift in Kenya

8.6 Areas of Tertiary sedimentation in Australia

9.1 New and old ocean basins

9.2 Structural elements of the Atlantic Ocean

9.3 Magnetic anomalies over the Reykjanes Ridge

9.4 Distribution of plateau-lavas and central volcanoes in Iceland

9.5 Mesozoic-Tertiary sedimentary prisms deposited at the Atlantic margin of North America

9.6 Central America and the Caribbean

9.7 Structural elements of the Indian Ocean and boundaries of the principal crustal plates

9.8 South-east Asia in Tertiary times

9.9 The Red Sea and Gulf of Aden, and relationships of the Arabian plate

10.1 Structural elements of the eastern Pacific Ocean

10.2 Magnetic profile across the East Pacific Rise illustrating the symmetry about the spreading centre

10.3 Mid-oceanic ridge system of the eastern Pacific in relation to the continent of North America

10.4 Principal magmatic provinces of the Pacific region

10.5 Island arcs and associated structures of the north-west Pacific

10.6 Deposition, igneous activity and tectonic activity in Japan

10.7 Paired metamorphic belts in Japan, and interpretive section of an island-arc system

10.8 Relationships of the lithospheric slab overridden at the Kermadec trench

10.9 Geological structure of New Zealand

11.1 Mobile belt of the western Americas, with principal granitic batholiths

11.2 Western mobile belt of North America

11.3 Cordilleran belt in Canada, with granites and metamorphic complexes

11.4 Central Cordillera

11.5 Miogeosynclinal zone of the northern Cordillera in Alberta

11.6 Phases of granite-emplacement in the central Cordillera set against 
11.7 Franciscan Formation in California, with metamorphic zones defined by laumontite, pumpellyite and lawsonite

11.8 Dyke swarms emplaced in relation to the rupturing of the American-African supercontinent

11.9 Geophysical anomalies in the western United States 330

11.10 Crustal section of the Andes 333

11.11 Evolution of some Phanerozoic mobile belts in the supercontinents of Gondwanaland and Laurasia

\section{List of Plates}

I The Upper Eleonore Bay Group in Berzelius Bjerg, Southern Lyellsland, East Greenland

II Glaciated pavement beneath Permian tillite, Pemganga river near Chandra, India

III The Matterhorn

IV Wase Rock, a volcanic plug south of Jos, Nigeria

V Fissure eruption close to the Atlantic spreading-centre in Iceland

VI Tertiary plateau-basalts at the continental margin in East Greenland 


\section{Preface}

When H. H. Read was asked by Macmillans to write an introductory text-book which would serve as the basis for a first University course in Geology, he originally hoped to cover the whole subject in a single volume. It soon became clear, however, that this could not be done unless much of the factual infomation needed by students was jettisoned. An enlargement of the project became necessary and as I was acting as his Research Assistant he invited me to join him. We decided to think in terms of a two-volume Introduction to Geology: Volume 1 (Principles) would deal with geological processes and with the rocks and structures produced by them, while Volume 2 (Earth History) would illustrate the effects of these processs by reference to the record of geological history. Volume 1 appeared in 1962 and we then began to make plans for Volume 2.

At this time, the scope of historical geology was being dramatically widened by new developments in the earth sciences. It seemed clear to us that if we were to provide the background which would be needed by students in the future we must deal with earth history on a world-wide basis and must cover the full span of geological time. This broad approach made it necessary to give the book a rather unusual balance and to scale down the treatment of some important topics usually favoured by stratigraphers and palaeontologists. The plan that we adopted allowed us to deal with the geological evolution of large crustal units over long time periods. The early stages in the history of these units are covered in Part I; the later stages, from a point in time about a thousand million years ago until the present day, are covered in Part II. Many of the themes introduced in Part I are developed in Part II, and I hope that the two Parts will be regarded for most purposes as an entity. The difficulties of producing a paperback as well as a hardcover version as a single large volume have made it preferable for Parts I and II to be published as separate but integrated books.

Soon after we had begun work on Volume 2, Professor Read suffered a severe illness which restricted his later activities. He pushed on, however, with undiminished enthusiasm and we kept in touch by means of innumerable letters and telephone conversations. About three-quarters of the manuscript had been written when he died in 1970, a few months after his eightieth birthday. Over the next year or so I completed the final chapters, revised the entire text and assembled material for the illustrations and bibliography. It falls to me, too, to thank the many people who have given us advice and information at many stages. In partcular, I must mention my colleagues at Imperial College, many of them former students or colleagues of $\mathrm{H}$. H. Read, who have helped to widen my horizons on many occasions. I also owe a debt of gratitude to Dr P. L. Robinson 
who has allowed me to use a photograph from her collection, and to many geologists in Europe, Canada, Africa and Australia who have made field excursions both profitable and enjoyable. In writing a book of this scope it is impossible to keep within the limits of one's own experience and although I am, of course, entirely responsible for errors of detail, I know how greatly the book has benefited from the experience and interest of those with whom I have discussed it.

\section{Acknowledgements}

The authors and publishers wish to thank the following who have kindly supplied the originals of the photographs mentioned:

The Director, Grфlands Geologiske, Unders $\phi$ gelse: Plates I and VI.

The Director, Lanmaelingar Islands: Plate V

Aerofilms Ltd: Plates III and IV

Dr P. L. Robinson, University College, London: Plate II 